\title{
Clinical significance of inflammatory indexes in patients with epithelial ovarian cancer
}

\section{Epitelyal over kanserli hastalarda inflamatuar indekslerin klinik önemi}

\author{
Ali Yılmaz ${ }^{1}$, Salim Başol Tekin ${ }^{1}$, Mehmet Bilici ${ }^{1}$, Hatice Yılmaz ${ }^{2}$ \\ ${ }^{1}$ Atatürk Üniversitesi Tıp Fakültesi, Tıbbi Onkoloji Bilim Dalı, Erzurum \\ ${ }^{2}$ Adnan Menderes Üniversitesi Tıp Fakültesi, Tıbbi Onkoloji Bilim Dalı, Aydın
}

Dergiye Ulaşma Tarihi: 03.04.2020 Dergiye Kabul Tarihi: 11.05.2020 Doi: 10.5505/aot.2020.38981

\section{ÖZET}

GİRIŞ ve AMAÇ: Sistemik inflamasyon ve immün yanıt kanser prognozu ile yakından ilişkilidir. Sistemik immüninflamasyon indeks (SII), prognostik nutrisyonel indeks (PNI) ve C-reaktif protein / albümin oranının (CAO) çeşitli kanserlerde prognostik olduğu bilinmektedir. Bununla birlikte, epitelyal over kanseri (EOK) vakalarında, inflamatuar indeksler hakkında çok az bilgi vardır. Bu nedenle biz bu çalışmada EOK hastalarında SII, PNI ve CAO gibi inflamasyon temelli indekslerin prognostik önemini araştırdık.

YÖNTEM ve GEREÇLER: EOK'lu 273 hasta retrospektif olarak çalışmaya dahil edildi. Klinik değişkenlerle progresyonsuz yaşam süresi (PYS) ve genel sağkalım (GS) arasındaki ilişki Kaplan - Meier yöntemi ile analiz edildi. En iyi sınır değerler ROC eğrisi analizi kullanılarak belirlendi. SII, PNI ve CAO sırasıyla 1559, 42.1 ve 3.11 kesme noktalarına göre sınıflandırıldı. GS için değişkenlerin prognostik önemi Cox regresyon modeli ile belirlendi.

BULGULAR: EOK hastalarında düşük SII ( $<1559)$, yüksek PNI $(\geq 42.1)$ ve düşük CAO $(<3.11)$ daha uzun PYS ve GS süreleri ile ilişkili bulundu. Tek değişkenli analizde yaş, menopoz durumu, ECOG skoru, epitelyal alt tip, evre, SII, PNI ve CAO'nun GS ile anlamlı ilişkisi vardı. Çok değişkenli analizde evre, SII ve PNI, GS için bağımsız prognostik faktörler olarak bulundu ( $\mathrm{p}<0.001, \mathrm{p}<0.024, \mathrm{p}<0.006$, sirasiyla).

TARTIŞMA ve SONUÇ: Tedavi öncesi SII ve PNI, EOK hastalarında GS'yi predikte etmek için kullanılabilecek prognostik biyobelirteçlerdir.

Anahtar Kelimeler: C-reaktif protein/albümin oranı, epitelyal over kanseri, prognostik nutrisyonel indeks, sistemik immün-inflamasyon indeks

\begin{abstract}
INTRODUCTION: Systemic inflammation and immune response are closely related to cancer prognosis. Systemic immune-inflammation index (SII), prognostic nutritional index (PNI) and C-reactive protein/albumin ratio (CAR) are known to be prognostic in various cancer. However, in epithelial ovarian cancer (EOC) cases, there is little information about inflammatory indexes. Therefore, we investigated the prognostic importance of inflammationbased indexes such as SII, PNI and CAR in EOC patients.

METHODS: Two hundred and seventy three patients with EOC were included in this study retrospectively. Relationship between clinical variables with progression-free survival (PFS) and overall survival (OS) were analyzed via Kaplan-Meier method. The best cut-off points were determined using a receiver operating characteristic (ROC) curve analysis. SII, PNI, and CAR were classified based on cutoff points 1559, 42.1 and 3.11, respectively. Prognostic importance of the variables for OS was determined with the Cox regression model. RESULTS: Low SII $(<1559)$, high PNI $(\geq 42.1)$ and low CAR $(<3.11)$, were found to be associated with longer PFS and OS times in patients with EOC. In univariate analysis, age, menopausal status, Eastern Cooperative Oncology Group (ECOG) score, epithelial subtype, stage, SII, PNI and CAR were significantly associated with OS. In multivariate analysis stage, SII and PNI were found to be independent prognostic factors for OS ( $p<0.001$, $\mathrm{p}<0.024, \mathrm{p}<0.006$, respectively).

DISCUSSION AND CONCLUSION: Pre-treatment SII and PNI are prognostic biomarkers that can be used to predict $\mathrm{OS}$ in patients with EOC.

Keywords: C-reactive protein/albumin ratio, epithelial ovarian cancer, prognostic nutritional index, systemic immune-inflammation index
\end{abstract}

\section{INTRODUCTION}

Ovarian cancer (OC) is one of the most frequently seen gynecological malignancies in women worldwide and common cause of gynecological cancer-related mortality [1]. Ninety-95 percent of ovarian malignancies 
originate from epithelial cells, while others from non-epithelial cell types (sex cord-stromal tumors, germ-cell tumors, etc.) [2]. The standard treatment of OCs, especially epithelial ovarian cancers (EOC), is surgery and then platinum-based chemotherapy regimens. However, 5-year survival is still below 50\% due to delayed diagnosis and early metastasis. Although previously, some markers as survivin, topoisomerase II $\alpha$, and $\mathrm{Ki}-67$ were used as the indicators of early diagnosis, and prognosis, promising results could not be obtained [3]. Therefore, it has become a necessity to use some biomarkers to determine the prognosis of patients with EOC and the course of the disease prior to treatment.

As is known, inflammation plays a fundamental role in tumorigenesis [4]. Systemic inflammation inhibits apoptosis, whereas it stimulates tumor proliferation, invasion, and angiogenesis [4]. Neutrophil, lymphocyte, monocyte, platelet counts and their relationship with each other are being used as systemic inflammatory indicators. Several immunoinflammatory based prognostic indexes, such as lymphocyte-monocyte ratio (LMR), neutrophillymphocyte ratio (NLR), and plateletlymphocyte ratio (PLR) have been shown to predict cancer recurrence in some solid tumors as prognostic factors [4]. Systemic immuneinflammation index (SII) is calculated by the combination of platelet, neutrophil and lymphocyte counts and reflects the balance between the host's inflammatory-immune condition. SII is a promising index for hepatocellular carcinoma (HCC), gastric cancer (GC), small-cell lung cancer (SCLC) and prostate cancer $[5,6]$. However, there are few data on the prognostic importance of SII in EOC [7]. Another marker, prognostic nutritional index (PNI), reflects the nutritional condition of the body as well as its immunological status and is calculated by a formula based on serum albumin concentration and lymphocyte count. The prognostic and predictive value of PNI has been demonstrated in some solid organ cancers, such as non-small cell lung cancer (NSCLC), HCC and GC, however there are limited number studies on EOC [8-10]. The C-reactive protein (CRP) to albumin ratio (CAR) is an immunoinflammatory indicator based on CRP and albumin that have active roles in tumor inflammation [11, 12]. CAR was initially identified to be related to prognosis of sepsis
[13]. Recently, the prognostic ability of CAR has been demonstrated in HCC, GC and esophageal carcinoma and high CAR values has been associated with the poor prognosis of patients [14-16]. However, the role of CAR in EOC is still unclear [17]. Therefore, in this investigation, we aimed to evaluate the prognostic impact of pre-treatment SII, PNI and CAR in EOC patients.

\section{METHODS}

Two hundred seventy three patients followed up for at least 6 months with the diagnosis of EOC between 2001 and 2018 in our center were included in the study. The files of the patients were retrospectively reviewed. Patients with a history of hematologic malignancy, active inflammatory disease, autoimmune disease, or history of another malignancy were excluded from the study. In addition, patients without CRP and albumin test results were excluded. Clinical variables such as menopausal status, age group, Eastern Cooperative Oncology Group (ECOG) score, International Federation of Gynecology and Obstetrics (FIGO) stage, disease progression and laboratory results such as neutrophil, albumin, CRP at the time of diagnosis were derived from data registry system. Pathological results such as subtype, estrogen and progesterone receptor status, were obtained from the pathology department data registry.

SII was obtained with the formula "platelet (P) x neutrophil (N) / lymphocyte (L)" and CAR values by using (CRP (mg/L) / albümin $(\mathrm{g} / \mathrm{dL}))$ formula. PNI results were obtained using the formula ' $(10 \times$ albumin $(\mathrm{g} /$ $\mathrm{dL})+(0.005 \times \text { total lymphocyte count })^{\prime}$.

All procedures performed in studies involving human participants were in accordance with the ethical standards of the institutional and national research committee and with the 1964 Declaration of Helsinki and its later amendments or comparable ethical standards. The study protocol was approved by the local ethics committee.

\section{Statistics}

Overall survival (OS) was defined as the time from diagnosis to death or the time from diagnosis to last follow-up for living patients. Progression-free survival (PFS) was defined as the time from diagnosis to death or recurrence, and the time from diagnosis to last follow-up for 
patients without recurrence. The association among clinicopathologic characteristics, PFS and OS was analysed using the Kaplan-Meier curves and log-rank tests. The receiver operating characteristic (ROC) curve analysis was used to determine the best cut-off points for parameters. Area under curve (AUC) values for SI, PNI and CAR \% 76, 79, 63 sensitivity and $\%$ 69, 71, 61 specificity were found in ROC analysis. The cut-off values for the highest sensitivity, specificity for SII, PNI, CAR were 1559, 42.1 and 3.11 respectively.

Cox regression analyses were used to evaluate the prognostic value of SII, PNI and CAR adjusted by menopausal status, age group, ECOG, histologic type of the EOC (serous, mucinous, other) and stage. Hazard ratios and 95\% confidence intervals (CIs) were estimated with Cox regression analysis. Statistical analysis was performed with SPSS 21 (SPSS IBM Corp. Armonk, NY, USA). p $<0.05$ was considered as statistically significant.

\section{RESULTS}

The median age of the 273 female patients enrolled in the study was $56(19-86)$ years, including $79(28.9 \%)$ premenopausal and 194 (71.1\%) postmenopausal women. There were $42(15.4 \%)$ patients with ECOG performance status 0, $120(44 \%)$ patients with I, $76(27.8 \%)$ patients with II and 35 (12.8\%) patients with IIIIV. The patients had serous ( $\mathrm{n}=220: 80.6 \%)$, mucinous $(n=24: 8.8 \%)$ and other type $(n=29$ $: 10.6 \%)$ EOCs. The patients had undergone curative surgery $(n=176: 64.5 \%)$, debulking surgery $(n=44: 16.1 \%)$, only biopsy $(n=53$ : $19.4 \%)$. Patients were in stages $I(n=64: 23.4 \%)$, II ( $\mathrm{n}=38: 13.9 \%)$, III $(\mathrm{n}=89: 32.6 \%)$, and IV $(\mathrm{n}=82: 30 \%)$ according to FIGO staging system. Sociodemographic and clinico-pathologic characteristics of the patients are shown in Table 1.

Table 1: Sociodemographic and clinicopathologic characteristics of the patients

\begin{tabular}{|l|l|l|}
\hline \multicolumn{2}{|l|}{ Parameters } & $\mathrm{n} /(\%)$ \\
\hline Age & $<65$ & $207(75.8)$ \\
\cline { 2 - 3 } & $\geq 65$ & $66(24.2)$ \\
\hline \multirow{2}{*}{$\begin{array}{l}\text { Menop } \\
\text { ausal }\end{array}$} & $\begin{array}{l}\text { Premenop } \\
\text { Status }\end{array}$ & $79(28.9)$ \\
\cline { 2 - 3 } & $\begin{array}{l}\text { Postmeno } \\
\text { pausal }\end{array}$ & $194(71.1)$ \\
\hline ECOG & 0 & $42(15.4)$ \\
& I & $120(44)$ \\
& II & $76(27.8)$ \\
\hline
\end{tabular}

\begin{tabular}{|c|c|c|}
\hline & III-IV & $35(12.8)$ \\
\hline \multirow[t]{2}{*}{ Smoker } & Yes & $55(20.1)$ \\
\hline & No & $218(79.9)$ \\
\hline \multirow{3}{*}{$\begin{array}{l}\text { Type of } \\
\text { Surgery }\end{array}$} & Curative & $176(64.5)$ \\
\hline & Debulking & $44(16.1)$ \\
\hline & Biopsy & $53(19.4)$ \\
\hline \multirow{2}{*}{\begin{tabular}{|l|} 
Lymph \\
Node \\
Dissection
\end{tabular}} & Present & $195(71.4)$ \\
\hline & Absent & $78(28.6)$ \\
\hline \multirow{2}{*}{$\begin{array}{l}\text { Estrogen } \\
\text { Receptor }\end{array}$} & Positive & $204(74.7)$ \\
\hline & Negative & $69(25.3)$ \\
\hline \multirow[b]{2}{*}{$\begin{array}{l}\text { Progester } \\
\text { one } \\
\text { Receptor }\end{array}$} & Positive & $132(48.4)$ \\
\hline & Negative & $141(51.6)$ \\
\hline \multirow{3}{*}{\begin{tabular}{|l|} 
Epithelial \\
Histology
\end{tabular}} & Serous & $220(80.6)$ \\
\hline & Mucinous & $24(8.8)$ \\
\hline & Other & $29(10.6)$ \\
\hline \multirow{3}{*}{$\begin{array}{l}\text { Platinum } \\
\text { Resistanc } \\
\text { e }\end{array}$} & Yes & 49 (17.9) \\
\hline & No & $195(71.4)$ \\
\hline & Unknown & $29(10.6)$ \\
\hline \multirow{4}{*}{$\begin{array}{l}\text { FIGO } \\
\text { Stage }\end{array}$} & I & $64(23.4)$ \\
\hline & II & 38 (13.9) \\
\hline & III & $89(32.6)$ \\
\hline & IV & $82(30)$ \\
\hline \multirow{2}{*}{$\begin{array}{l}\text { Progressio } \\
\mathrm{n}\end{array}$} & Yes & $176(64.5)$ \\
\hline & No & $97(35.5)$ \\
\hline \multirow[t]{2}{*}{ Status } & Alive & $144(52.7)$ \\
\hline & Death & $129(47.3)$ \\
\hline
\end{tabular}

ECOG: Eastern Cooperative Oncology Group, FIGO: International Federation of Gynecology and Obstetrics

The median period of follow-up was 39 (3-142) months while 176 (64.5\%) cases progressed and 129 (47.3\%) patients died. At the time of analysis, the median PFS and OS were 24 and 53 months, respectively. According to the age groups; There was a statistically significant difference between $<65$ and $\geq 65$ groups in terms of PFS (28 vs. $12, \mathrm{p}<0.001$, respectively) and OS times (63 vs. $26, \mathrm{p}<$ 0.001 , respectively). PFS / OS times in premenopausal women were 63 / 102 months which were longer relative to postmenopausal (18 / 41 months) women with a statistically significant intergroup difference $(\mathrm{p}<0.001, \mathrm{p}<$ 0.001). PFS / OS were $36 / 69,28 / 72,20 / 36$, 11 / 31 months in ECOG 0, I, II, III-IV groups respectively, and the difference between the groups was significant (p: 0.001, p $<0.001$ ). Overall and progression-free survival times for clinicopathological parameters and SII, PNI, CAR are shown in Table 2. According to the epithelial subtype, the median PFS and OS times for mucinous and other group were not 
reached, but there were a statistically significant difference between the epithelial subtypes for both PFS and OS ( $<<0.001, \mathrm{p}: 0.010)$. The longest PFS / OS times (66 / 104 months) were detected in stage I, followed by stages II (46 / 102 months), III (20 / 37 months), IV (8 / 21 months), and these PFS and OS times were significant $(p<0.001, p<0.001)$.

The highest sensitive and specific cut off values for SII, PNI and CAR were determined with ROC analysis. Among the prognostic parameters, the PNI has the highest AUC (0.79). AUC values for SII (0.76) and CAR (0.63) were found as indicated. Median SII, PNI and CAR are 1566.6, 42.5, 4.2 respectively. The cases with low SII had longer PFS (38 vs 18 months, $\mathrm{p}<0.001)$ and OS (102 vs 32 months, $\mathrm{p}<0.001)$ times when compared to those with higher SII values. Patients with a PNI score of $\geq 42.1$ had significantly longer PFS / OS times (PFS: 41 vs. 18 months, p <
0.001, OS: 102 vs 30 months, p < 0.001) (Fig. 1). The cases with low CAR had longer PFS (36 vs 19 months, $\mathrm{p}<0.001$ ) and OS (49 vs 36 months, $\mathrm{p}<0.001)$ times when compared to those with higher CAR values. OS curves of SII, PNI, CAR are shown in Fig 2.

In the multivariate analysis FIGO stage (HR: 1.773; 95\% CI: 1.431-2.197; p < 0.001), SII (HR: 1.607 ; 95\% CI: 1.066-2.423; p: 0.024) and PNI (HR: 0.551; 95\% CI: 0.361-0.842; p: 0.006 ) were found to be independent prognostic factors for OS. But multivariate analysis showed that age (HR: 1.220 ; 95\% CI: 0.8171.822; p: 0.331), menopausal status (HR: 1.171; 95\% CI: 0.702-1.953; p: 0.545), ECOG (HR: 1.157; 95\% CI: 0.934-1.433; p: 0.182), epithelial histology (HR: 1.010; 95\% CI: 0.6881.483; p: 0.958) and CAR (HR: $1.250 ; 95 \%$ CI: $0.831-1.881 ; \mathrm{p}: 0.283)$ were not associated with OS (Table 3).

Table 2: Overall and progression-free survival times according to clinical-pathological parameters and, SII, PNI, CAR

\begin{tabular}{|c|c|c|c|c|c|c|c|c|}
\hline & $\begin{array}{l}\text { Total } \\
\text { (n) }\end{array}$ & $\begin{array}{l}\text { Total } \\
(\%)\end{array}$ & PFS & & & OS & & \\
\hline & & & Mean & Median & $p$ & Mean & Median & $p$ \\
\hline \multicolumn{9}{|l|}{ Age } \\
\hline$<65$ & 207 & 75.8 & 59.9 & 28 & $<0.001$ & 76.3 & 63 & $<0.001$ \\
\hline$\geq 65$ & 66 & 24.2 & 30.1 & 12 & & 46.1 & 26 & \\
\hline \multicolumn{9}{|l|}{$\begin{array}{l}\text { Menopausal } \\
\text { Status }\end{array}$} \\
\hline Premenopausal & 79 & 28.9 & 78.8 & 63 & $<0.001$ & 94 & 102 & $<0.001$ \\
\hline Postmenopausal & 194 & 71.1 & 39.9 & 18 & & 55.8 & 41 & \\
\hline \multicolumn{9}{|l|}{ ECOG } \\
\hline 0 & 42 & 15.4 & 51.7 & 36 & 0.001 & 73.9 & 69 & $<0.001$ \\
\hline I & 120 & 44 & 64 & 28 & & 81.7 & 72 & \\
\hline II & 76 & 27.8 & 31.7 & 20 & & 45.6 & 36 & \\
\hline III-IV & 35 & 12.8 & 21 & 11 & & 36.1 & 31 & \\
\hline \multicolumn{9}{|l|}{ Smoker } \\
\hline Yes & 55 & 20.1 & 66.5 & 28 & 0.070 & 77.3 & 63 & 0.152 \\
\hline No & 218 & 79.9 & 47.6 & 23 & & 64.8 & 49 & \\
\hline \multicolumn{9}{|l|}{$\begin{array}{l}\text { Estrogen } \\
\text { Receptor }\end{array}$} \\
\hline Positive & 204 & 74.7 & 63.7 & 27 & 0.116 & 67.6 & 60 & 0.943 \\
\hline Negative & 69 & 25.3 & 47.3 & 23 & & 65.7 & 49 & \\
\hline \multicolumn{9}{|l|}{$\begin{array}{l}\text { Progesterone } \\
\text { Receptor }\end{array}$} \\
\hline Positive & 132 & 48.4 & 50.6 & 21 & 0.504 & 72.5 & 60 & 0.161 \\
\hline Negative & 141 & 51.6 & 51.8 & 27 & & 62.7 & 49 & \\
\hline \multicolumn{9}{|l|}{$\begin{array}{l}\text { Epithelial } \\
\text { Histology }\end{array}$} \\
\hline Serous & 220 & 80.6 & 42.5 & 21 & $<0.001$ & 61.3 & 45 & 0.010 \\
\hline Mucinous & 24 & 8.8 & 62.5 & $\mathrm{nr}$ & & 62.6 & $\mathrm{nr}$ & \\
\hline Other & 29 & 10.6 & 98.6 & $\mathrm{nr}$ & & 104.8 & $\mathrm{nr}$ & \\
\hline \multicolumn{9}{|l|}{ FIGO Stage } \\
\hline I & 64 & 23.4 & 91.8 & 66 & $<0.001$ & 93.5 & 104 & $<0.001$ \\
\hline
\end{tabular}




\begin{tabular}{|l|l|l|l|l|l|l|l|l|}
\hline II & 38 & 13.9 & 81.5 & 46 & & 90.2 & 102 & \\
\hline III & 89 & 32.6 & 28.5 & 20 & & 47 & 37 & \\
\hline IV & 82 & 30 & 15.5 & 8 & & 38.1 & 21 & \\
\hline SII & & & & & & & & \\
\hline$<1559$ & 136 & 49.8 & 67.5 & 38 & $<\mathbf{0 . 0 0 1}$ & 91.8 & 102 & $<\mathbf{0 . 0 0 1}$ \\
\hline$\geq 1559$ & 137 & 50.2 & 37.9 & 18 & & 50.2 & 32 & \\
\hline PNI & & & & & & & & \\
\hline$<42.1$ & 132 & 48.4 & 35 & 18 & $<\mathbf{0 . 0 0 1}$ & 46.7 & 30 & $<\mathbf{0 . 0 0 1}$ \\
\hline$\geq 42.1$ & 141 & 51.6 & 69.2 & 41 & & 92.8 & 102 & \\
\hline CAR & & & & & & & & \\
\hline$<3.11$ & 116 & 42.5 & 64.2 & 36 & $<\mathbf{0 . 0 0 1}$ & 88.3 & 49 & $<\mathbf{0 . 0 0 1}$ \\
\hline$\geq 3.11$ & 157 & 57.5 & 41.1 & 19 & & 51.7 & 36 & \\
\hline Overall & 273 & 100 & 51.5 & 24 & & 67.9 & 53 & \\
\hline
\end{tabular}

Statistically significant $p$ values are in bold $(p<0.05)$, nr: not reached, PFS: Progression-Free Survival, OS: Overall Survival, ECOG: Eastern Cooperative Oncology Group, FIGO: International Federation of Gynecology and Obstetrics, SII:Systemic Immune-Inflammation Index, PNI: Prognostic Nutritional Index, CAR: CRP /Albumin Ratio

Table 3: Univariate and multivariate analysis of potential prognostic factors for overall survival Parameters

Multivariate

\begin{tabular}{|c|c|c|c|c|}
\hline & HR & $\mathrm{p}$ & HR & $\mathrm{p}$ \\
\hline Age $(<65$ vs $\geq 65)$ & \begin{tabular}{|l|}
2.084 \\
$(1.442-$ \\
$3.0122)$ \\
\end{tabular} & $<0.001$ & $\begin{array}{l}1.220 \\
(0.817- \\
1.822) \\
\end{array}$ & 0.331 \\
\hline $\begin{array}{l}\text { Menopausal } \\
\text { Status } \\
\text { (pre vs post) }\end{array}$ & \begin{tabular}{|l|}
2.494 \\
$(1.590-$ \\
$3.911)$ \\
\end{tabular} & $<0.001$ & $\begin{array}{l}1.171 \\
(0.702- \\
1.953) \\
\end{array}$ & 0.545 \\
\hline $\begin{array}{l}\text { ECOG (0 vs I vs } \\
\text { II vs III-IV) }\end{array}$ & \begin{tabular}{|l|}
1.530 \\
$(1.260-$ \\
$1.858)$ \\
\end{tabular} & $<0.001$ & $\begin{array}{l}1.157 \\
(0.934- \\
1.433) \\
\end{array}$ & 0.182 \\
\hline Smoker & $\begin{array}{l}0.718 \\
(0.453- \\
1.136)\end{array}$ & 0.157 & & \\
\hline \begin{tabular}{|l|} 
Estrogen \\
Receptor
\end{tabular} & \begin{tabular}{|l|}
1.014 \\
$(0.685-$ \\
$1.501)$ \\
\end{tabular} & 0.943 & & \\
\hline $\begin{array}{l}\text { Progesterone } \\
\text { Receptor }\end{array}$ & $\begin{array}{l}0.780 \\
(0.550- \\
1.108) \\
\end{array}$ & 0.165 & l- & \\
\hline $\begin{array}{l}\text { Epithelial } \\
\text { Histology } \\
\text { (serous vs } \\
\text { mucinous vs } \\
\text { other) }\end{array}$ & $\begin{array}{l}0.576 \\
(0.397- \\
0.836)\end{array}$ & 0.004 & $\mid \begin{array}{l}1.010 \\
(0.688- \\
1.483)\end{array}$ & 0.958 \\
\hline FIGO Stage & $\begin{array}{l}2.118 \\
(1.747- \\
2.567) \\
\end{array}$ & $<0.001$ & \begin{tabular}{|l|}
1.773 \\
$(1.431-$ \\
$2.197)$ \\
\end{tabular} & $<0.001$ \\
\hline $\begin{array}{l}\text { SII ( }<1559 \text { vs } \\
\geq 1559)\end{array}$ & $\begin{array}{l}2.677 \\
(1.832- \\
3.911) \\
\end{array}$ & $<0.001$ & $\begin{array}{l}1.607 \\
(1.066- \\
2.423)\end{array}$ & 0.024 \\
\hline $\begin{array}{l}\text { PNI (<42.1 vs } \\
\geq 42.1)\end{array}$ & \begin{tabular}{|l}
0.321 \\
$(0.219-$ \\
$0.469)$ \\
\end{tabular} & $<0.001$ & $\begin{array}{l}0.551 \\
(0.361- \\
0.842) \\
\end{array}$ & 0.006 \\
\hline $\begin{array}{l}\text { CAR }(<3.11 \text { vs } \\
\geq 3.11)\end{array}$ & $\begin{array}{l}2.158 \\
(1.493- \\
3.117) \\
\end{array}$ & $<0.001$ & $\begin{array}{l}1.250 \\
(0.831- \\
1.881)\end{array}$ & 0.283 \\
\hline
\end{tabular}

Statistically significant $p$ values are in bold $(p<0.05)$ PFS: Progression-Free Survival, OS: Overall Survival, ECOG: Eastern Cooperative Oncology Group, FIGO: International Federation of Gynecology and Obstetrics,
SII:Systemic Immune-Inflammation Index, PNI: Prognostic Nutritional Index, CAR: CRP/Albumin Ratio
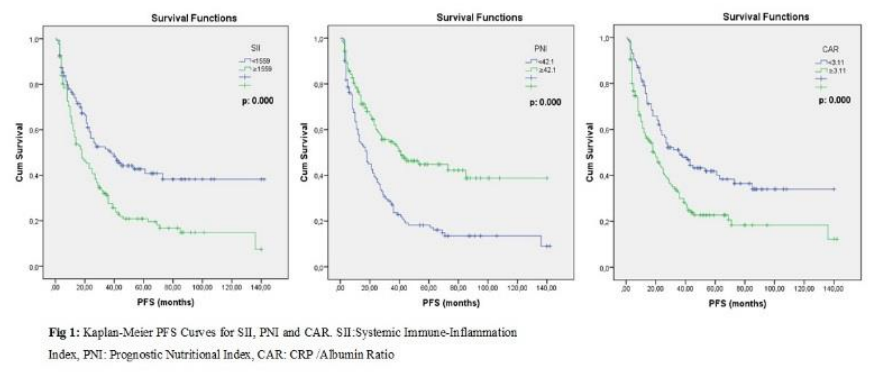
Inder, PN: Pronnosic Nurritional Inder, CAR: CRP A A Abumin Ratio
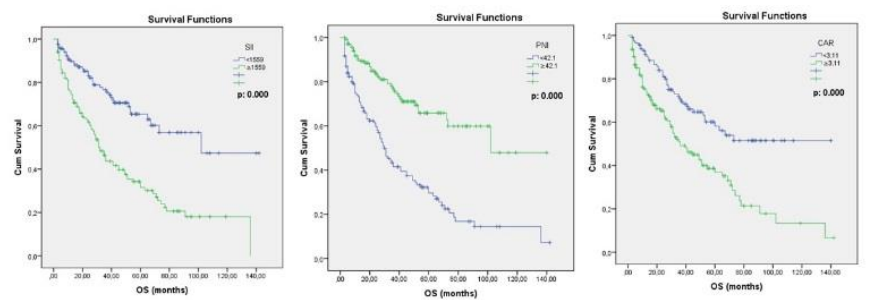

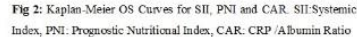

\section{DISCUSSION}

Recently, increasing amount of evidence asserted that systemic inflammatory response plays a critical role in the carcinogenesis and increases the risk of tumor development, triggers genetic mutations and promotes tumor progression and metastasis [18]. These evidence suggest that the inflammatory parameters might be good predictors of prognosis in cancer patients. Therefore, we investigated to evaluate the prognostic importance of inflammatory indices in EOC. We found that stage, SII and PNI were independent prognostic factors in both 
univariate and multivariate analysis for OS but CAR was only in univariate analysis. Our results are important in predicting prognosis and guiding the treatment strategy in EOC.

The tumor microenvironment triggers systemic inflammation through proinflammatory mediators. This condition results in proliferation of tumor cells, stimulation of angiogenesis and inhibition of apoptosis. Neutrophils in peripheral blood are indicators of both acute and chronic inflammatory processes. Neutrophils not only suppress the activity of Natural Killer cells and lymphocytes, but also inactivate already activated $\mathrm{T}$ cells, which is the basis for the suppression of the immune system by neutrophils. Besides, neutrophils also activate oncogenic cytokines and chemokines such as vascular endothelial growth factor, matrix metalloproteinase-9, interleukin (IL)-1 $\beta$, IL-12, IL-6 and tumor necrosis factor (TNF) $-\alpha$ and indirectly regulate the tumor microenvironment to stimulate tumor growth [19]. On the other hand, lymphocytes induce cytotoxic cell death and play a critical role in clearing tumor cells by inhibiting the proliferation of tumor cells. Platelets can mediate the growth, survival and spread of tumor cells into distant regions. It is thought that they exert these functions by increasing the synergistic effect between TGF $\beta 1$ / Smad and NF-stress pathways, providing epithelial-mesenchymal passage and by protecting circulating tumor cells from fragmentation stress in the circulation [20].

SII is an index based on the correlation of inflammatory markers including platelets, neutrophils and lymphocytes. SII is calculated based on three inflammatory cell types and may be a more sensitive marker reflecting the host's inflammatory-immune balance when compared with scorings assessed by the ratio of two types of inflammatory cells, such as NLR, LMR and PLR. Hu et al. demonstrated that in patients diagnosed as HCC with SII scores over 330 had increased recurrence and decreased survival rates [6]. In two studies of lung cancer patients, SII was found to be an independent prognostic factor for OS in 919 SCLC cases [5], whereas in 140 NSCLC cases SII was found to be an independent prognostic factor for both PFS and OS

[21].

Yang et al. published a meta-analysis including 7196 patients and demonstrated that SII has prognostic significance for both PFS and OS in various types of cancer including esophageal carcinoma, gastric and renal cancer [22]. In a study conducted with 375 patients with EOC, the patients who received chemotherapy alone in the first-line treatment were compared with those who received bevacizumab in combination with chemotherapy and SII was shown to be a predictor of bevacizumab activity. In this study, it was shown that receiving chemotherapy with bevacizumab in patients with high SII (cut -off: 730) scores did not provide survival advantage over monotherapy [23]. Nie et al. found that high SII $(\geq 612)$ was associated with PFS and OS in EOC and found SII as an independent prognostic factor for PFS/OS [7]. In our study, we showed that patients with SII $\geq 1559$ in EOC cases had shorter PFS and OS similar to the results of other studies. We found SII to be an independent prognostic factor in multivariate analysis for OS. However, there is limited data on the importance of SII in patients with EOC, and these results should be confirmed with other studies.

PNI is another inflammatory based index reflects the nutritional and immunological condition of the person in combination of albumin and total lymphocyte counts. Albumin synthesis is often used to assess the patient's nutritional status and severity of the disease because its levels decrease in cases of malnutrition and inflammation [24]. In recent years, PNI has been used as a prognostic and predictive marker in various cancer types. In a study of patients with colorectal cancer (CRC), Mohri et al showed that the incidence of postoperative complications increased while survival rates decreased in patients with PNI indexes lower than 45 [25]. In a meta-analysis 3203 GC patients, it was shown that the lower PNI scores were associated with decreased OS rates compared to those with higher PNI scores [10]. The data on OC about PNI are limited. Miao et al. found that patients with lower PNI $(<45)$ scores had shorter PFS and OS times in 344 patients with EOC [26]. In a study conducted with 875 cases with high grade serous OC, low PNI (cut- off: 45.45) was found to be correlated with advanced stage, increased CA125, widespread ascites, residual disease, platinum resistance and decreased survival rates [27]. In another study by Zhang et al, 237 patients with stage III OC, the lower PNI score 
(cut- off: 47.2) was shown to be a poor prognostic factor for PFS and OS [28]. Similar to previous studies, we found that in patients with EOC, higher PNI scores had provided significant advantage as for PFS and OS compared to those with lower PNI scores. Both univariate and multivariate analyses showed that PNI was prognostic for OS.

Another inflammation-based marker CAR, which is obtained from the ratio of CRP and albumin, may reflect both the inflammatory and nutritional status. As an acute phase reactant CRP is one of the important markers of inflammation and has a negative correlation with albumin that reflects the nutritional status of the host [29]. Recently, the CAR has been used as a prognostic factor for many solid organ malignancies such as gastric and pancreatic cancer [13]. In a study of 240 patients with oral squamous cell carcinoma, pre-treatment high CAR $(\geq 0.525)$ was shown to be poor prognostic factor for OS and disease-free survival (DFS) [13]. In a meta-analysis of approximately 3000 patients, in esophageal cancer, low CAR has been shown to provide significant OS and DFS advantage [11]. In another meta-analysis, 1942 patients with CRC were involved, and a high pretreatment CAR was associated with poor prognosis in CRC [30]. However, there are limited studies investigating the predictive importance of CAR in patients with OC. In only one study, Liu et al. found that preoperative CAR (cut-off: 0.68) was an independent prognostic factor for OS in 200 patients with OC. Additionally they demonstrated that CAR shows superior prognostic ability compared to the established inflammatory indices such as glasgow prognostic score and PNI [17]. In our study we showed that lower CAR $(<3.11)$ associated with longer PFS and OS in patients with OC. However, in multivariate analysis we found that CAR was not an independent prognostic factor for OS. In addition, PNI had the highest AUC (0.79) among the inflammation-based indexes, unlike Liu et al. Therefore, PNI was found as a superior predictive factor than SII and CAR for survival in patients with EOC.

In this study, for the first time, the prognostic significance of the three inflammatory indexes were evaluated all together. Finally, SII and PNI, especially PNI, are important markers for predicting survival and determining treatment strategy in patients with EOC. However, we think it would be beneficial to confirm these results with future prospective studies.

There were several important limitations to our study. Firstly, our study is a retrospective trial. Secondly, there was no healthy control group in our study.

\section{CONCLUSION}

EOC which is most common histologic type of the OCs, is still an important cause of mortality and morbidity. Therefore, it is important to predict prognosis to determine treatment strategies in EOC. SII and PNI are independent prognostic factors for OS in patients with EOC. Moreover, compared to other inflammation based indexes, PNI shows superior prognostic ability. PNI is an easy and reproducible biomarkers that can be used in routine practice.

\section{Acknowledgements}

Funding: This research received no specifc grant from any funding agency in the public, commercial, or not-for-proft sectors.

Conflict of Interest: The authors declare that they have no conflict of interest.

\section{References}

1. Siegel R, Ma J, Zou Z, Jemal A. Cancer statistics, 2014. CA Cancer J Clin. 2014; 64:9

2. Lacey JV, Sherman ME. Ovarian neoplasia. Robboy's Pathology of the Female Reproductive Tract, 2nd ed, Robboy SL, Mutter GL, Prat J, et al. (Eds). Churchill Livingstone Elsevier, Oxford 2009. p.601.

3. Kucukgoz Gulec U, Gumurdulu D, Guzel $\mathrm{AB}$, et al. Prognostic importance of survivin, $\mathrm{Ki}-67$, and topoisomerase $\mathrm{II} \alpha$ in ovarian carcinoma. Arch Gynecol Obstet. 2014; 289(2):393-8

4. Kargin S, Cakir M, Gundes E, et al. Relationship of preoperative neutrophil lymphocyte ratio with prognosis in gastrointestinal stromal tumors. Ulus Cerrahi Derg. 2015;31(2):61-4.

5. Hong X, Cui B, Wang M, et al. Systemic immune-inflammation index, based on platelet counts and neutrophil-lymphocyte ratio, is useful for predicting prognosis in small cell lung cancer. Tohoku J. Exp. Med. 2015; 236(4), 297-304.

6. $\mathrm{Hu} \mathrm{B}, \mathrm{Yang} \mathrm{XR}, \mathrm{Xu}$ Y, et al. Systemic immune-inflammation index predicts prognosis of patients after curative resection for hepatocellular carcinoma. Clin. Cancer Res. 2014; 20(23): 6212-22.

7. Nie D, Gong H, Mao X, et al. Systemic immune-inflammation index predicts 
prognosis in patients with epithelial ovarian cancer: A retrospective study. Gynecologic Oncology. 2019; 152(2):259-264.

8. Tomitaa M, Ayabea T, Maedaa R, et al. Comparison of Inflammation-Based Prognostic Scores in Patients undergoing Curative Resection for Non-small Cell Lung Cancer. World J Oncol. 2018; 9(3):85-90.

9. Wang Z, Wang J, Wang P. The prognostic value of prognostic nutritional index in hepatocellular carcinoma patients: A metaanalysis of observational studies. PLoS One. 2018; 13(10):e0202987.

10. Wang SH, Zhai ST, Lin H. Role of Prognostic Nutritional Index in patients with gastric cancer: a meta-analysis. Minerva Med. 2016;107(5):322-7.

11. Wang $\mathrm{Y}, \mathrm{Hu} \mathrm{X}$, Huang $\mathrm{Y}$, et al. Prognostic value of the $\mathrm{C}$-reactive protein to albumin ratio in esophageal cancer: A systematic review and meta-analysis. Kaohsiung J Med Sci. 2020 Jan;36(1):54-61.

12. Forrest LM, McMillan DC, McArdle CS, et al. Evaluation of cumulative prognostic scores based on the systemic inflammatory response in patients with inoperable nonsmall-cell lung cancer. Br J Cancer. 2003; 89(6):1028-30.

13. Wang Q, Song X, Zhao Y, et al. Preoperative high c-reactive protein/albumin ratio is a poor prognostic factor of oral squamous cell carcinoma. Future Oncol. 2019;15(19):2277-2286.

14. Kinoshita A, Onoda H, Imai N, et al. The Creactive protein/albumin ratio, a novel inflammation-based prognostic score, predicts outcomes in patients with hepatocellular carcinoma. Ann Surg Oncol. 2015;22(3):803-10.

15. Liu X, Sun X, Liu J, et al. Preoperative Creactive protein/albumin ratio predicts prognosis of patients after curative resection for gastric cancer. Transl Oncol. 2015;8(4):339-45

16. Wei XL, Wang FH, Zhang DS, et al. A novel inflammation-based prognostic score in esophageal squamous cell carcinoma: the Creactive protein/albumin ratio. BMC Cancer. 2015;15:350.

17. Liu $\mathrm{Y}$, Chen $\mathrm{S}$, Zheng $\mathrm{C}$, et al. The prognostic value of the preoperative $\mathrm{c}$ reactive protein/albumin ratio in ovarian cancer. BMC Cancer. 2017;17(1):285.

18. Ostan R, Lanzarini C, Pini E, et al. Inflammaging and Cancer: A Challenge for the Mediterranean Diet. Nutrients. 2015; 7(4):2589-2621.

19. Bausch D, Pausch T, Krauss T, et al. Neutrophil granulocyte derived MMP-9 is a VEGF independent functional component of the angiogenic switch in pancreatic ductal adenocarcinoma

2011;14(3):235-243.

Angiogenesis.

20. Labelle M, Begum S, Hynes RO. Direct signaling between platelets and cancer cells induces an epithelial-mesenchymal-like transition and promotes metastasis. Cancer cell 2011; 20(5):576-590.

21. Guo D, Zhang J, Jing W, et al. Prognostic value of systemic immune-inflammation index in patients with advanced non-smallcell lung cancer Future Oncol 2018;14(25):2643-2650.

22. Yang R, Chang Q, Meng X, et al. Prognostic value of Systemic immune-inflammation index in cancer: A meta-analysis. Journal of Cancer. 2018; 9(18): 3295-3302.

23. Farolfi A, Petrone M, Scarpi E, et al. Inflammatory indexes as prognostic and predictive factors in ovarian cancer treated with chemotherapy alone or together with bevacizumab. A multicenter, retrospective analysis by the MITO Group (MITO 24). Target. Oncol. 2018;13(4):469-479.

24. Ballmer PE, Ochsenbein AF, SchutzHofmann S. Transcapillary escape rate of albumin positively correlates with plasma albumin concentration in acute but not in chronic inflammatory disease. Metabolism. 1994; 43(6):697-705.

25. Mohri $\mathrm{Y}$, Inoue $\mathrm{Y}$, Tanaka $\mathrm{K}$, et al. Prognostic nutritional index predicts postoperative outcome in colorectal cancer. World J Surg. 2013; 37(11): 2688-92.

26. Miao Y, Li S, Yan Q, et al. Prognostic significance of preoperative prognostic nutritional index in epithelial ovarian Cancer patients treated with platinum-based chemotherapy. Oncol Res Treat. 2016;39(11):712-9.

27. Feng Z, Wen H, Ju X, et al. The preoperative prognostic nutritional index is a predictive and prognostic factor of high-grade serous ovarian cancer. BMC Cancer. 2018; 18(1):883.

28. Zhang W, Ye B, Liang W, et al. Preoperative prognostic nutritional index is a powerful predictor of prognosis in patients with stage III ovarian cancer. Scientific RePorts. 2017; 7(1): 9548.

29. Dolan RD, McSorley ST, Horgan PG, et al. The role of the systemic inflammatory response in predicting outcomes in patients with advanced inoperable cancer: Systematic review and meta-analysis. Critical Reviews in Oncology/Hematology. 2017; 116:134-146.

30. Wang F, Li P, Li FS. Prognostic role of Creactive protein to albumin ratio in colorectal cancer: A meta analysis. Medicine (Baltimore). 2019; 98(29):e16064. 